\title{
Frederick II of Hohenstaufen and modern ecology
}

\author{
Pekka Niemelä1, Timo Vuorisalo², Simo Örmä ${ }^{3}$
}

\begin{abstract}
Emperor Frederick II's early thirteenth-century book on falconry, De arte venandi cum avibus, is probably the most famous single source for scholars who survey the state-of-the-art in natural sciences in medieval times. Most of the research on his book has focused on the marginal illustrations featuring about 80 bird species. However, the book contains a large amount of ethological, ecological, morphological and faunistic knowledge about bird fauna. Frederick was also one of the first to conduct experiments with birds. Here, we describe the ornithological experiments and observations of Frederick and evaluate them from the perspective of modern ecology.

In many contexts, Frederick expressed criticism of Aristotle and his work Liber Animalium. Frederick's observation upon the geographical variation of species was partially in contrast to the Aristotelian typological or essentialist species concept. This is an important finding from the point of view of the western history of biology.

De arte venandi cum avibus demonstrates Frederick's deep knowledge of the ecology, morphology and behaviour of birds. This knowledge he gained via his long practice with falconry. The love of falconry made Frederick an early proponent of empiricism, and De arte venandi cum avibus was actually the most important achievement of empirical zoology in the thirteenth century.
\end{abstract}

Key Words: Aristotle's criticism, bird migration, De Arte Venandi cum Avibus, Medieval natural history, predation, species geographical variation.

Riassunto - Federico II di Hohenstaufen e la moderna ecologia Il libro dell'imperatore Federico II dell'inizio del XIII secolo sulla falconeria, De arte venandi cum avibus, è probabilmente la fonte singola più famosa per gli studiosi che indagano lo stato dell'arte delle scienze naturali in epoca medievale. La maggior parte della ricerca su questo libro si è concentrata sulle illustrazioni marginali raffiguranti circa 80 specie di uccelli. Tuttavia, il libro contiene una grande quantità di conoscenze etologiche, ecologiche, morfologiche e faunistiche

${ }^{1}$ Biodiversity unit, FI-20014, University of Turku, Finland. E-mail: pekka.niemela@utu.fi

2 Department of Biology, FI-20014, University of Turku, Finland. E-mail: timo.vuorisalo@utu.fi

${ }^{3}$ Institutum Romanum Finlandiae, Passeggiata del Gianicolo 10, 00165 Roma, Italia.

* Corresponding author: orma@irfrome.org

(C) 2021 Pekka Niemelä, Timo Vuorisalo, Simo Örmä

Received: 27 April 2021

Accepted for publication: 10 September 2021

Online publication: 29 October 2021 sull'avifauna. Federico fu anche uno dei primi a condurre esperimenti sugli uccelli. Qui, descriviamo gli esperimenti ornitologici e le osservazioni di Federico e li valutiamo dal punto di vista della moderna ecologia.

In molti contesti, Federico espresse una critica ad Aristotele e alla sua opera Liber Animalium. Le osservazioni di Federico sulla variazione geografica delle specie erano in parte in contrasto con il concetto aristotelico di specie tipologica o essenzialista. Si tratta di una scoperta importante dal punto di vista della storia occidentale della biologia.

Il De arte venandi cum avibus dimostra la profonda conoscenza di Federico dell'ecologia, della morfologia e del comportamento degli uccelli. Questa conoscenza è stata acquisita grazie alla sua lunga pratica nel campo della falconeria. L'amore per la falconeria fece di Federico un precoce fautore dell'empirismo, e il De arte venandi cum avibus fu effettivamente il più importante risultato della zoologia empirica nel XIII secolo.

Parole chiave: critica di Aristotele, De Arte venandi cum Avibus, migrazione degli uccelli, predazione, storia naturale medievale, variazione geografica delle specie.

\section{INTRODUCTION}

In the Middle Ages, falconry was a popular hobby among European royalty and nobles. However, it had much longer historical roots. According to Wood \& Fyfe $(1955)^{1}$, "falconry was familiar to the peoples of China, ancient India, Assyria, Sumeria, and the other provinces of Babylonia, Egypt, and Persia thousands of years before Rome came into existence". According to Egerton (2003), however, the earliest evidence for falconry dates back to the court of Sargon II in Mesopotamia during the eighth century BCE. The custom of hunting with raptors seems to have been introduced to Europe some time during the Middle Ages, since falconry as such was unknown in antiquity in the Western world (Oggins, 2004). The usefulness of this innovation was probably perceived quickly, since at the time "the only chance of bringing down birds which flew out of the range of arrows was to send falcons after them" (Wood \& Fyfe, 1955: xxxv) (Fig. 1).

Frederick II of Hohenstaufen (1194-1250) was the Holy Roman Emperor and the King of the Norman kingdom of Sicily, and later the King of Jerusalem. He was an excellent administrator, lawgiver, soldier and diplomat, and a great patron of learning and the arts (Oggins, 2004: $3)$. Unfortunately, his reign was characterized by conflicts with the Papacy, and he was excommunicated twice (Egerton, 2003: 40-41). Frederick, called by contempora- 
ries "the wonder of the world", was also a first-rate naturalist and an early practitioner of the experimental method (Oggins, 2004: 4-5). Frederick II's book on falconry, De arte venandi cum avibus, has become a standard source for scholars who survey the state-of-the-art in natural sciences during medieval times. He probably wrote or dictated it in the later part of his life (ca. 1244-48) after thirty years of practical experience and data collection (Oggins, 2004: 5).

The original manuscript itself written by Frederick II was lost as booty to his enemies immediately after the battle of Parma in 1248. However, essential fragments and material of both texts and illustrations of the lost manuscript remained at Frederick's Apulian castles. De arte venandi cum avibus has survived in two editions, called by the critics the "short" edition and the "long" edition, attributed to the two sons of the Emperor, Manfred and Enzo. Of the short edition, which contains only two books, we have only two manuscripts: the famous Pal. Lat. 1071 of the Vatican Library with splendid illustrations and addenda by King Manfred during his reign as the King of Sicily (1258-1266), and a late manuscript in Vienna (Österreichische Nationalbibliothek, ms. 10948). The long version in six books was probably made in Bologna by Enzo, another illegal son of Frederick, and is still conserved in the University Library of Bologna (lat. 717 ). The total number of surviving manuscript copies is thirteen: two in "short version", five in "long version", one consisting only of Liber IV of the "long version" and five translations into Old French of the "short version" (Trombetti Budriesi, 2009).

The edition of the book Codex Ms. Pal. Lat. 1071 is well known because of the marginal illustrations of about 800 figures featuring at least 80 bird species or taxonomic groups. So far, the main focus of the research on Frederick's book has been on these illustrations and species identification (Willemsen, 1980) ${ }^{2}$. However, the book contains a large amount of behavioural, ecological, morphological and faunistic knowledge concerning birds. Frederick also conducted many experiments with his vul- tures, falcons and hawks. This aspect of the book has received very little attention.

Recently there has been discussion about the existence of another book about falconry by Frederick, a treatise on the various types of hunting, including with dogs and thrown weapons (Trombetti Budriesi, 2009: 9). This would not be surprising, as several practical manuals on falconry existed already before Frederick's time (Egerton, 2003: 40).

The long version of Frederick's falconry book contains a general prologue and six main books: Book I: The structure and habits of birds; Book II: Of falcons used in hunting, their furniture, care and manning; Book III: On the use of the lure; on training falcons to fly in a cast; on educating gerfalcons to fly at cranes, and on hounds used in falconry; Book IV: Crane hawking with gerfalcons and other falcons; Book V: Heron hawking with sakers and other falcons; and Book VI: Hawking at the brook with the peregrine falcon. The main division is thus between the more general introductory parts and the more technically oriented later parts. Interesting ornithological observations are to be found throughout the entire volume.

Frederick's approach to scientific questions was very modern, in that he distinguished between theory and practice. In the introductory part of his book about falconry, he stated: "Our main thesis, then, is The Art of Falconry; and this we have divided into two cardinal sections. The first contains the argument, by which we mean contemplative thought, or theory; the second illustrates practice, which portrays experimental action." (Wood \& Fyfe, 1955: 4). By theory, he obviously referred to books I and II, which describe the general ecology of birds, and by practice, to books III-VI, which discuss the practice of hawk hunting. Frederick continued: "In addition, a third subsection contains a part of the argument and includes certain data pertaining to both theory and practice. Our purpose is to present the facts as we find them" (Wood \& Fyfe, 1955: 4).

The objective of our article is to review Frederick's importance as an early experimentalist and an independent natural historian. His pioneering role as an experimen-

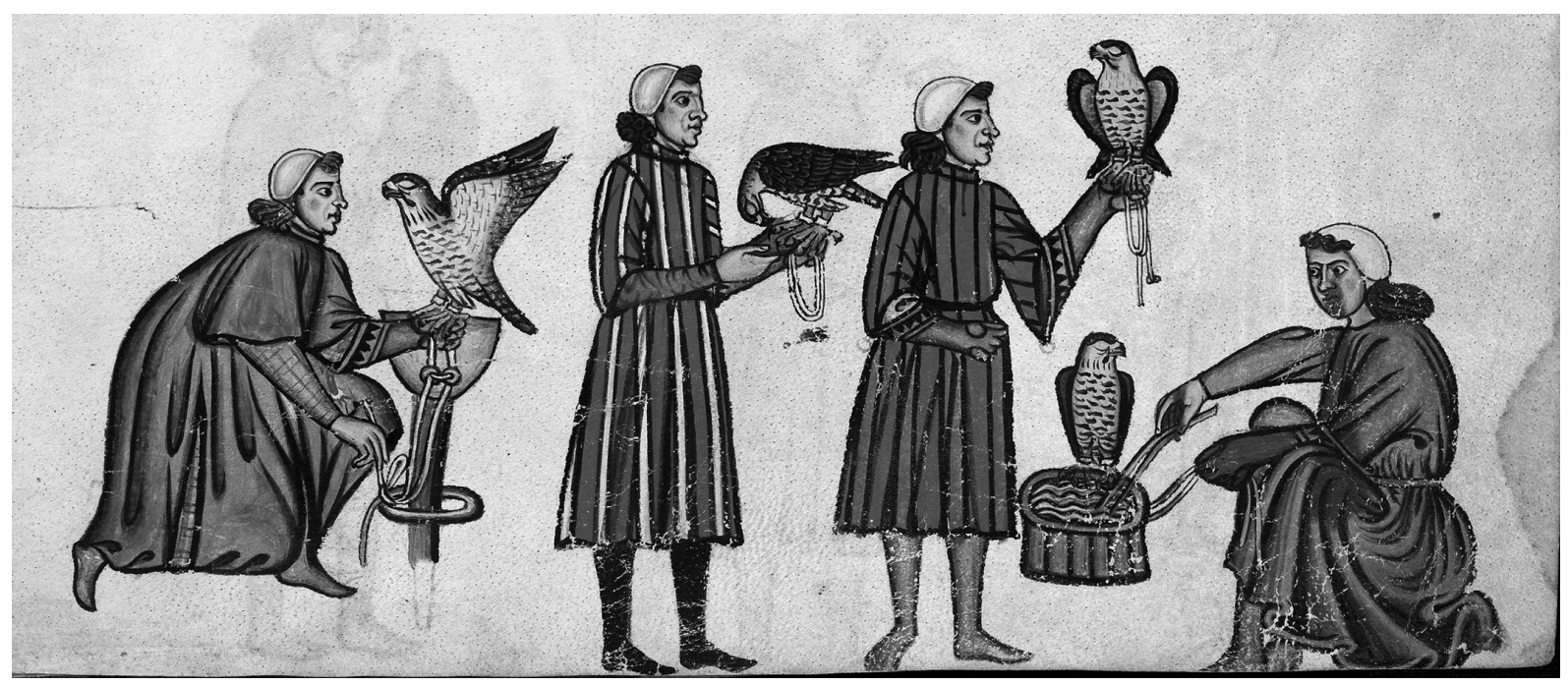

Fig. 1 - Falconers training and taking care of their falcons. / Falconieri che addestrano e si prendono cura dei loro falchi. (C) Biblioteca Apostolica Vaticana, Pal.lat.1071: f.79r. 
talist has been acknowledged at least since Wood \& Fyfe $(1955)^{3}$. Egerton (2003: 41-42) mentioned the numerous ecological and behavioural observations of De Arte Venandi, but did not pursue the topic further. So far, no detailed analyses of his experimental approaches or ecological thinking have been published, with the exception of some biogeographical observations (Niemelä et al., 1991). Specific attention will be paid to Frederick's relations to Aristotelian natural historical thinking and the historically important essentialist species concept. In our study, we have utilized the translation made by Wood \& Fyfe, 1955.

\section{ARISTOTELIAN BACKGROUND AND ITS CRITICISM}

The great Greek philosopher Aristotle would doubtless have been surprised to learn that his influence would dominate the study of life for the next 2,000 years. Although he is often seen as a developer of his teacher Plato's ideas, he did not adapt very well to his intellectual surroundings and was at times out of favour with the authorities. Disagreements meant that he was not elected as Plato's successor, and after the death of his famous pupil Alexander the Great, he had to flee to the island of Euboea, where he later died in exile (Nordenskiöld, 1928). Although he was not a political leader, his intellectual career was somewhat reminiscent of that of Frederick II. Both were great and unorthodox synthesizers, and excellent observers, albeit in different fields (Mayr, 1982).

Through his writings, however, Aristotle more or less dominated the growth of Western thought until the scientific revolution of the seventeenth and eighteenth centuries. He was said to have written 400 books, of which only about 48 have survived to the present. An important reason for his popularity was that his ideas were in the Middle Ages embraced by the Church. In natural history, Aristotle's authority was rarely questioned. Ernst Mayr ironically described the medieval approach to natural historical phenomena: "When an argument arose as to how many teeth the horse has, one looked it up in Aristotle rather than in the mouth of a horse" (Mayr, 1982: 93).

Aristotle's contributions to the science of life were important and diverse. He was interested in the diversity of the world, and recognized two classification categories, the "genos" and the "eidos", the latter roughly corresponding to a species, while the "genos" applied to various groupings of higher degree (Leroi, 2014: 88-90). Like other Greek philosophers, he thought that harmony and order prevail in nature and that everything had been created to fulfil a particular purpose. He has justly been called the father of the comparative method. In his writings, he compared the anatomy, reproductive biology and behaviour of animals. All animals were classified into "blooded" or "bloodless" forms. He was also greatly impressed by the importance of the four main elements - i.e. fire, water, earth, and air - and ranked hot above cold, and moist above dry. According to Aristotle, "hotter and moister" creatures were supposed to be rational whereas "colder and dryer" creatures had less vital heat and thus lacked the higher type of "soul". This type of natural phi- losophy was very popular among the Renaissance Aristotelians (Mayr, 1982: 20).

Although later criticized by Frederick for some of his claims, Aristotle was a keen observer. He recognized about 140 species of birds and was aware of the difference between whales and fish, and of the anatomical equivalency of birds' feathers and reptiles' scales. He was the first to study the development of the chicken embryo systematically. He was, however, also influenced by some misconceptions of his time. For instance, he assumed that swallows Hirundo rustica hibernate, rather than migrate as some other birds do (Leroi, 2014: 253-254).

Aristotle was a supporter of the essentialist species concept, according to which each species is characterized by its unchanging essence (eidos) and is sharply separated from all other species. All those objects that share the same "essence" belong to the same species. Essentialism claims that individuals do not stand in any special relation to each other. They are merely expressions of the same "eidos". The variation observed is the result of imperfect manifestations of the "eidos" (Mayr, 1982: 256-258). Aristotle believed in well-defined and unchanging species, and definitely held no evolutionary ideas.

Unlike Aristotle, Emperor Frederick was a man of a single important manuscript. He started his criticism of Aristotle already on the first page of his book: "Inter alia, we discovered by hard-won experience that the deductions of Aristotle, whom we followed when they appealed to our reasons, were not entirely to be relied upon, more particularly in his descriptions of characters of certain birds" (Wood \& Fyfe, 1955: 3-4). Frederick continued: "In his work, the Liber Animalium, we find many quotations from other authors whose statements he did not verify and who, in their turn, were not speaking from experience. Entire conviction of the truth never follows mere hearsay" (fidesque certa non provenit ex auditu) (Wood \& Fyfe, 1955: 4; Trombetti Budriesi, 2009: 4).

Frederick's criticism of Aristotle's work was thus more or less based on unsatisfactory details he picked up in Aristotle's writings. For example, he recalled that Aristotle had not himself seen nests or nestlings of vultures, or how birds actually use their mandibles. Frederick also had several objections to Aristotle's observations on bird migration: "The calls of migrating cranes, herons, geese, and ducks may be recognized flying overhead even during the night, and not as Aristotle claims, as a part of their efforts in flight; they are the call notes of one or more birds talking to their fellows" (Wood \& Fyfe, 1955: 34). And concerning the migration flocks: "It is not true, as Aristotle asserts, that the same leader heads the migrant column during the whole of their journey" (Wood \& Fyfe, 1955: 40).

There are several other examples where Frederick did not follow Aristotle. Most corrections Frederick made were disagreements on definitions. Frederick was a much better observer of nature than Aristotle or his followers. (Egerton, 2003: 41). For example, Frederick classified birds into three categories: waterfowl, land birds and neutral birds. Here he criticized the classification made by Aristotle: "Although Aristotle declares that every creature may be classed either as a water resident or as a terrestrial 
animal, and that only fish are truly aquatic, and includes under the term of land animals all those that process both by walking and flying, yet he does not make the mistake of classifying all winged creatures as birds" (Wood \& Fyfe, 1955: 7). Frederick further divided predatory birds into three sub-groups based on their mode of food acquisition (Egerton, 2003: 42-43).

Also, in the context of how aquatic birds forage for their food, Frederick criticized Aristotle, who had claimed that "birds that are limited in flight are to an equal extent good pedestrians". According to Frederick, cormorants do not fit Aristotle's proposition, as they are even worse walkers than fliers (Wood \& Fyfe, 1955: 15). Frederick's son Manfred later added that the adaptedness of cormorants to swimming makes them awkward both on land and in the air (Egerton, 2003: 42). A third example of Frederick's criticism of Aristotle concerned the definition of raptorial birds. According to Aristotle, rapacious birds were "greedy-clawed" birds or "birds of the hooked claws" (Wood \& Fyfe, 1955: 9). Frederick did not accept this definition, since also jackdaws, larger swallows and vultures have hooked claws and are nevertheless not called raptors.

In spite of Aristotle's criticism in the manuscript, the Aristotelian influence is still evident in many parts of the manuscript. When Frederick reasoned about what could be explained by what is now known as Bergmann's rule, i.e. why birds are larger in the north compared to southern areas, he said that "they are larger because, in the seventh climate and further north, the intense cold tempers their inherent intense heat, thereby increasing humidity, and because the augmentation of humidity enlarges their members, and in that way the magnitude of the body is effected" (Niemelä et al., 1991: 33-34), Here Frederick clearly referred to the humoralism system which dominated Greek and Roman medicine.
Frederick was also critical of another great ancient scholar, Pliny, and his statement about the Phoenix bird: "It is said that there are certain harmless species that consist entirely of a single male and a unique female, and that the phoenix belongs to such species. This, however, we do not believe" (Wood \& Fyfe, 1955: 109).

\section{ADAPTATION AND WITHIN-SPECIES GEOGRAPHICAL VARIATION}

Frederick received hunting hawks at his court in Sicily practically from all over Europe, including continental North Europe, Iceland and Greenland. Frederick thus had an excellent opportunity to compare geographical differences in size, colouration, behaviour and morphology among different hawk species and, perhaps more importantly, among individuals within species. (Fig. 2).

It has been shown earlier that Frederick was the first to present the so-called Bergmann's rule (Dementiev 1935; Niemelä et al., 1991). This well-known biogeographical rule established by Carl Bergmann in 1847 states that warm-blooded vertebrates from cooler climates tend to be larger than individuals living in warm climates.

In his book about falconry, Frederick wrote: "Universaliter autem omnes aves rapaces quae nascuntur in septimo climate, et ultra, versus polum arcticum sunt maiores, fortiores, audaciores, pulcriores, meliores et velociores quaelibet autem in specie sua" ("As a rule, rapacious birds born in the seventh climatic zone and still further north in the direction of the arctic pole are larger, stronger, more fearless, more beautiful and swifter, but everyone within its own species"; Wood \& Fyfe, 1955: 39). The term 'seventh climatic zone' referred to the division of climatic zones by the Arab Muslim geographer Muhammad al-Idrisi who spent twenty-five years at the court of Roger II, the maternal grandfather of Frederick (Trombetti Budriesi, 2009: 11-12).

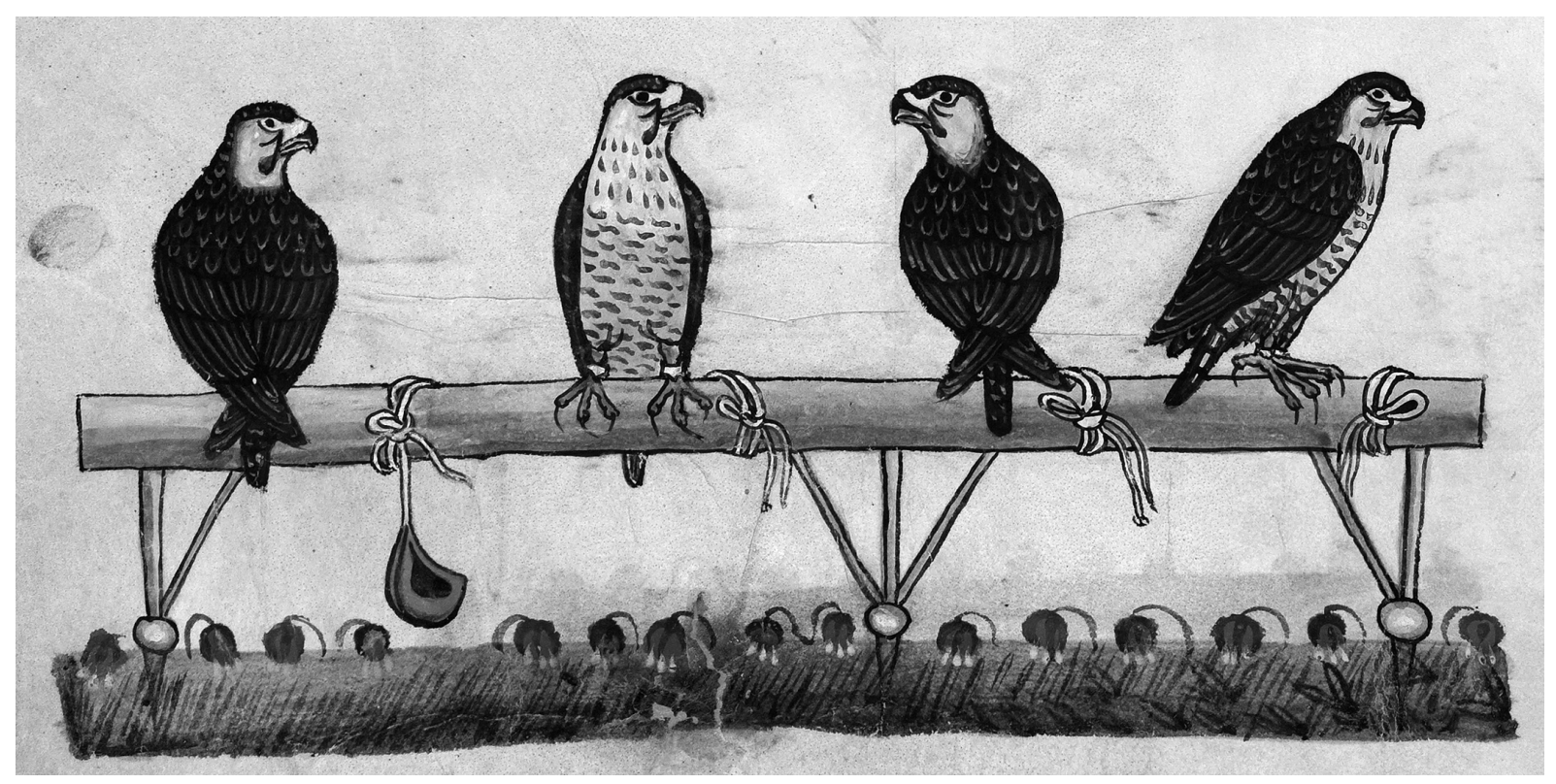

Fig. 2 - Frederick received hunting falcons and hawks from the different parts of Europe, which gave him an opportunity to compare plumage and morphology among individuals and species from different areas. / Federico ricevette falconi e falchi da caccia dalle diverse parti d'Europa, il che gli diede l'opportunità di confrontare il piumaggio e la morfologia tra individui e specie di diverse aree. (C) Biblioteca Apostolica Vaticana, Pal.lat.1071: f.55v. 
Frederick based his rule on morphological and behavioural differences he observed between hawks from the Mediterranean area and those he received from Northern Europe, Iceland and Greenland. It is important to note that Frederick was speaking of intraspecific variation ( $a u$ tem in specie sua).

Frederick handled his specimens of birds which originated from separate areas and populations displaying geographic variation. In doing so, he carried out what Mayr has called "the rejection of essentialism with its insistence of the constancy of the species essence". It is also notable that Frederick also recognized the geographical variation of humans, i.e. the existence of human races. However, he pointed out that this variation in the size and colouration does not cause different races to belong to different species (Niemelä et al., 1991: 41).

This outlook on the geographical intraspecific variation of species was in clear contrast to the Aristotelian (typological or essentialist) species concept and was demonstrated in Frederick's statement: "diversitas enim regionum, colorum et morum non facit homines aut animalia esse diverse specie" ("but variation in colour, habits and place of origin do not cause either men or animals to belong to different species"). The essentialist species concept did not deny the possibility of variation within species. However, such variation was considered to be a random outcome of effects of the organisms' surroundings, with no adaptive value (Niemelä et. al., 1991: 41).

Thanks to his knowledge of intraspecific variation, Frederick may even have pondered over some evolutionary ideas. For example, in describing the colours of avian plumage he mentioned that "[e]ven in the same species one finds examples of variation in colour, either of the whole bird or of single feathers" (Wood \& Fyfe, 1955: 80). When describing the different organs of birds Frederick wrote: "Structural differences the young bird inherits chiefly from his ancestors. If all birds were uniformly constructed, their members would exhibit in detail a corresponding uniformity of function, no matter how many species were presented, but avian organs show a great diversity in form and appearance so much that individuals may be distinguished one from another. These variations are at times so marked that they at once divide bird life into various categories". In addition, he writes: "It must be remarked that creative power has allocated to the proper place material naturally adapted to the formation of various organs and has endowed each one with a construction resembling that of the parent bird." (Wood \& Fyfe, 1955: 56-57). At the very least, Frederick seems to have understood the role of adaptation.

Although Frederick seems to have had some ideas about evolution and adaptation, the idea of natural selection, the basic element of Darwinian evolutionary theory, was unknown to him: "Nature is not only benevolent in one species and malevolent in another but, what is more important, exhibits her two opposite aspects at the same time, for each species finds in another what is harmful to it" (Wood \& Fyfe, 1955: 57).

\section{PREDATION}

Predation is one of the main ecological interactions. The role of predation is crucial in evolution, since it leads to adaptations via natural selection both in prey and predator populations. Predation also plays an important role in the population dynamics of animals, trophic-level interactions, ecosystem processes, and in shaping animal communities. Hunting with hawks is a form of predation and thus it is no wonder that Frederick paid much attention to the role of predation. He tended to explain many phenomena he saw in nature by predation. (Fig. 3).

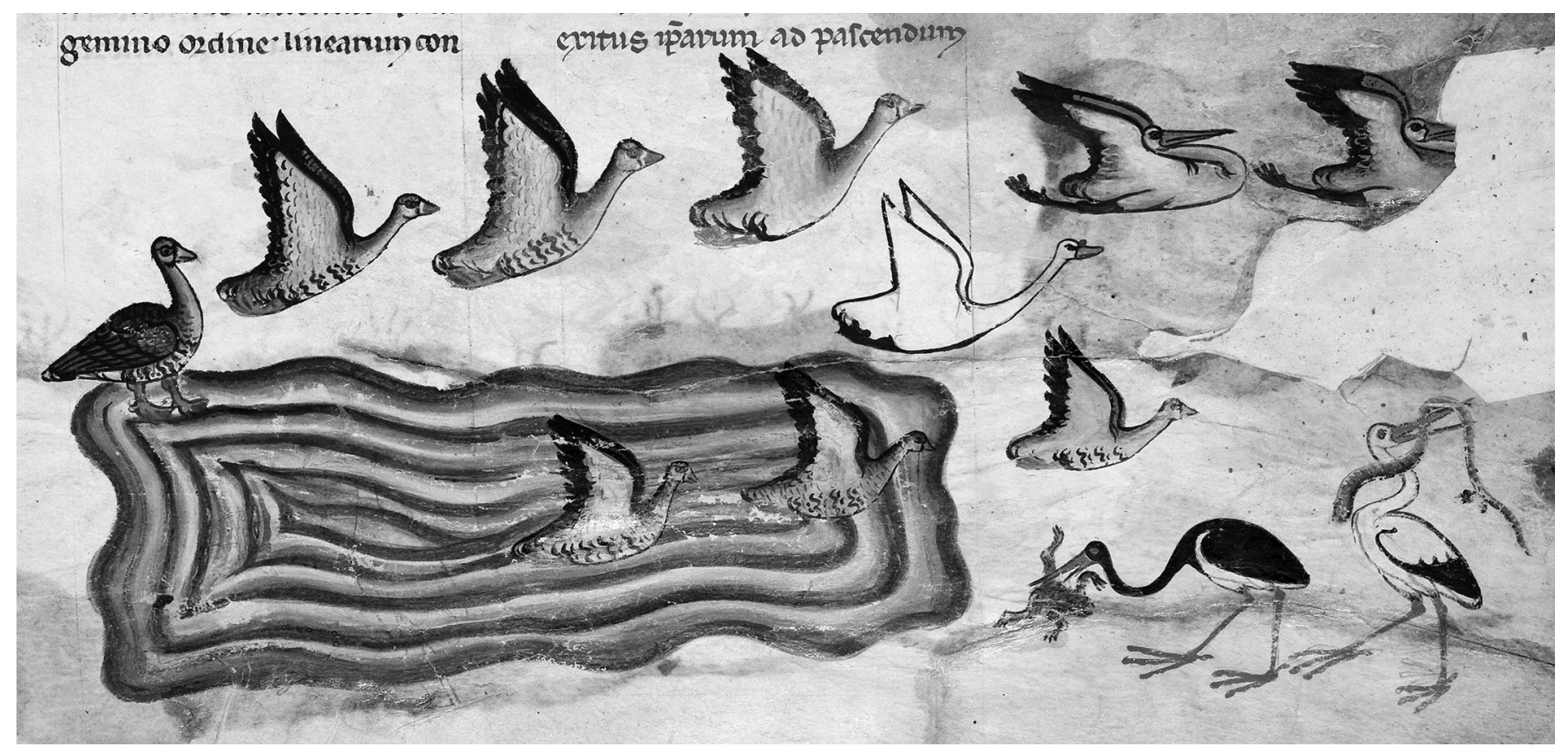

Fig. 3 - Predation by a Black Stork and a European White Stork (below right). / Una cicogna nera e una cicogna bianca in predazione (in basso, a destra). (C) Biblioteca Apostolica Vaticana, Pal.lat.1071: f.7r. 
According to Frederick, predation affects the diurnal movements of birds. Among water birds "only those with moderate powers of movement and slight ability to fly, such as cormorants and coots, make this journey by night, and then solely because of their fear of birds of prey." $\mathrm{He}$ continued: "The localities they choose for feeding vary greatly according to the character of the food, the season of the year, and the ease of escape from birds of prey." And finally: "Their home-coming takes place during the day, that they may guard against such wild animals as fish otters, foxes, and birds of prey." (Wood \& Fyfe, 1955: 16-18). Frederick explained the night hunting of owls by avoidance of attacks by bird parents defending their nests and nestlings (Egerton, 2003: 2; Wood \& Fyfe, 1955: 95, 97).

Frederick mentioned that, for example, the snipe does not fly during the daytime for fear of birds of prey. Frederick also realized that the flocking behaviour of birds may be an adaptation against predation by raptorial birds. He mentioned that flying in flocks is typical of pigeons and starlings.

A significant and strikingly modern discovery by Frederick was the observation that there are fewer individuals in higher levels of trophic food chains than in lower levels. (He did not, however, use the modern term food chain.) He wrote that "birds of prey are fewer in number than harmless birds and are always land birds and never belong to either natural species or to waterfowl" (Wood \& Fyfe, 1955: 109).

Frederick's physical explanation of why many waterfowl and many other bird species tend to sleep on one foot is very interesting. The reason for this phenomenon is fear of predation, and Frederick's explanation was based on classical mechanical physics: Nearly all birds sleep on one foot so that "they may sleep lightly and are easily alarmed and readily awakened to meet approaching danger. Water birds asleep with one foot in the water readily sense any disturbance of the surrounding fluid and are thus warned of the approach of beasts of prey or enemies. Since water is liquid and its limits are ill-defined, it recedes from the point of disturbance with a circular motion that extends to the leg of the bird, who, feeling the motion, is instantly alarmed and put on guard. Moreover, a body that has several points of support stands more firmly and is more difficult to move than one resting less securely. Hence a bird resting on one foot only is easily roused." (Wood \& Fyfe, 1955: 19).

\section{RELATION BETWEEN THE SEXES}

Mate choice is important, because it partially determines the genetic quality of an individual's offspring. Frederick noted that "the pairing of male and female is for the purpose of breeding. Pairing is a preliminary to coitus, which, in its turn, is followed by breeding". The mate selection process is thereafter described as follows: "As soon as birds feel the impulse to mate and reproduce, they select their partner in the following manner: They return to their native country, or to a locality that closely resembles it, if for any reason it is not available. At this time more than at any other, birds give voice to various cries, frequently singing and whistling. By these calls males and females recognize each other, and particular cries are indicative of a desire for coitus. Not only do males distinguish the notes of females, and vice versa, but each individual bird can identify its mate by the sound of his or her voice. When birds have made their choice, they pair off and usually forsake all others" (Wood \& Fyfe, 1955: 45-46).

Frederick thus acknowledged the fact that some choice of partner takes place but did not relate mate choice to any particular physical characteristics of individuals of the opposite sex. He clearly emphasized the role of birds' voices in the process.

Frederick was aware of the fact that in some raptor species the female is larger than the male, a trait not widespread in the animal kingdom, where the female is nearly always either smaller or of the same size as the male. Frederick's explanation of this phenomenon sounded Aristotelian: "in birds of prey the natural sexual coldness of the female tempers or abates her heat" and the consequence is that females are larger than males (Wood \& Fyfe, 1955: 109).

\section{PARENT-OFFSPRING CONFLICT AND KIN SELECTION}

Frederick was interested in the reproductive behaviour of birds. He wrote that "last year's fledglings, mindful of the food furnished by the parents, are not inclined to leave them until they themselves reach the age for mating or until they are otherwise prevented from following their parents or are actually driven off by them". And later: "But in every instance fledglings are driven away and, if they are unwilling to go, the parents use force and even beat their offspring to prevent them from interfering with the new brood by destroying the nest, breaking the eggs, or killing the occupants" (Wood \& Fyfe, 1955: 45-46).

These observations by Frederick clearly refer to a phenomenon that Robert L. Trivers has more recently called parent-offspring conflict (Trivers, 1974). Trivers claimed that parent and offspring are expected to disagree over how long the period of parental investment should last, over the amount of parental investment that should be given, and over the altruistic and egoistic tendencies of the offspring as these tendencies affect other relatives. Trivers' model has thereafter become one of the cornerstones of behavioural ecology. (Fig. 4).

Frederick appears even to have been aware of the need to avoid resource competition between close kin: "Birds of prey actually feed their young for a longer period than do many nonrapacious species but drive them off sooner to look out for themselves. Were raptorial adults and their fledglings to hunt in company, parents and young would prove no exception to the rule that birds of prey rob one another of their quarry. Injuries would follow on each side, and an unhappy state of affairs would result. Therefore, it is essential for the mother bird to expel her brood in early life and thereafter "walk alone" (Wood \& Fyfe, 1955: 56). Avoidance of resource competition among close relatives is consistent with the predictions of kin selection theory (Michod, 1982). 


\section{BIRD MIGRATION}

That many birds perform seasonal migrations has been known since prehistoric times. It seems that Frederick was the first to analyse in detail both the phenomenon itself and its causes. In The Art of Falconry, he discussed bird migration most specifically in chapters I, 54- I, 88. This is not surprising, since Sicily is located in the middle of one the main migration routes of European birds.

Frederick's list of questions related to bird migration showed great interest in the background of the phenomenon: "why they follow this or that course, how they prepare for their journey, the time of the year they set out, the sort of weather that influences them, which of them depart the soonest and why, what order they maintain in their flight, from what localities they depart, at what points they descend to earth and rest during their migrations, and finally, their ultimate destination, and for what purpose and how long they remain there". This list shows great understanding of avian biology and is still valid for contemporary migration research.

Generally speaking, autumn migration starts when birds "have gained their full strength and plumage". Migrant birds are found among both aquatic and terrestrial birds. Not all birds migrate; in addition to injured individuals of migratory species, there are many species that do not migrate at all. These include, for instance, partridges, pheasants and bustards. Although residential birds do not migrate, they may change their living grounds between breeding season and winter: "in winter, perhaps, they fly from hills to valleys nearby and in summer come back again from the valleys to the mountains" (Wood \& Fyfe, 1955: 31-32).

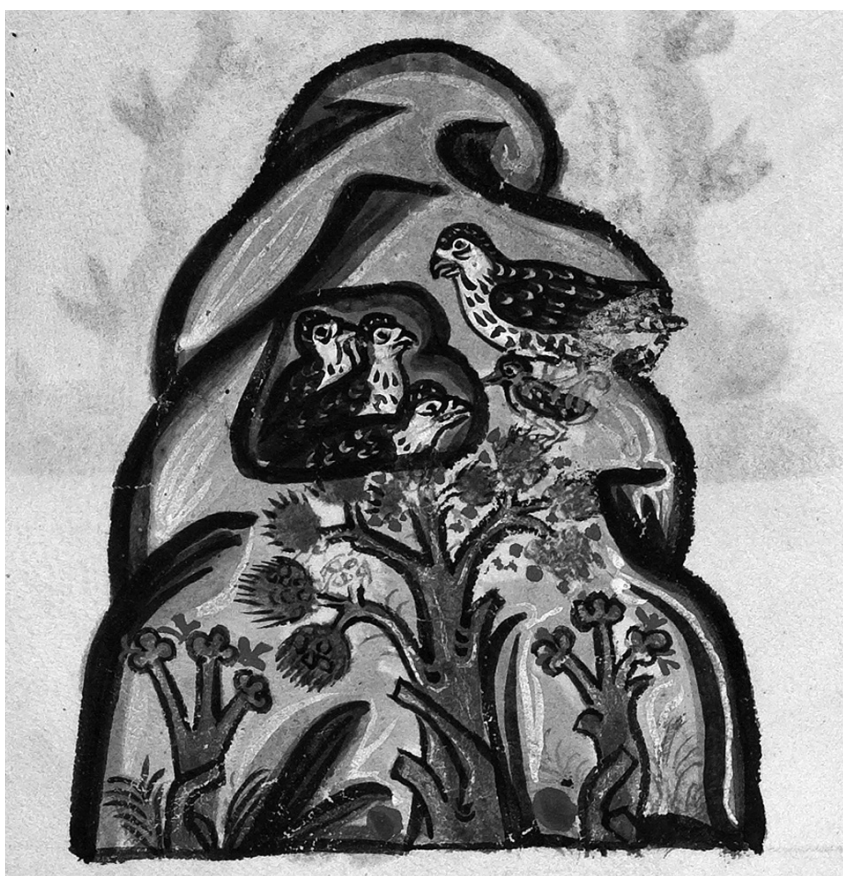

Fig. 4 - Frederick was aware of the fact that nestlings and young birds may desire more food and care than their parents are willing to provide them (parent-offspring conflict). / Federico si rese conto del fatto che i nidiacei e i giovani uccelli possono desiderare più cibo e cure di quelle che i loro genitori sono disposti a fornire loro (conflitto genitori-figli). (C) Biblioteca Apostolica Vaticana, Pal.lat.1071: f.51v.
Frederick proceeded to analyse the causes of seasonal migrations. He considered weather as the single most important reason for bird migration. "Birds enjoy a mild temperature", and therefore birds primarily migrate to avoid excessively cold or alternatively very hot weather. Other possible causes for autumn migration are increasing difficulties in obtaining food in frozen land or waters, adverse weather conditions (heavy rains, storms, and snowfall) and for aquatic species loss of shelter in their frozen aquatic resorts. Such birds cannot escape their predators by diving in frozen waters. Predatory birds, in turn, need to migrate to follow their prey species (Wood \& Fyfe, 1955: 42).

Birds (excluding raptors) prepare for autumn migration by flocking. They wait "for a day favourable to their long journey". Birds choose a period of mild and favourable winds for their migration, and in autumn the north winds are favoured. The timing of migration depends on the geographical location of the breeding grounds. Frederick had also observed the flock formations of migrating birds. Unlike what Aristotle had claimed, the leader of the flock varies as the birds take turns in the leading task (Wood \& Fyfe, 1955: 33). (Fig. 5).

Frederick specifically observed the behaviour of predatory birds at the onset of autumn migration: "Birds of prey leave in the autumn with other migrating birds when the weather is favourable, whether that be at night or in the daytime. They immediately forsake their food and forego their sleep if the wind blows in the right quarter. We have ourselves observed that they abandon food thrown to them that they have been preparing for consumption just as soon as a breeze favourable for the journey springs up." (Wood \& Fyfe, 1955: 119).

Interestingly, Frederick also compared autumn and spring migration. Both have the same primary cause, i.e. the search for moderate temperatures. However, the returning flocks in spring are usually smaller than those in the autumn migration due to high mortality during the latter, and in the wintering grounds. In spring, "birds are more irregular in their flight and less concerned with others of their species". Spring migration is also more rapid as birds hasten to their breeding grounds. Frederick remarked on habitat selection in spring: "Migration is made not to fixed areas but to whatever regions afford them food, mild temperatures, and security" (Wood \& Fyfe, 1955: 44). Nest site fidelity is however common, because birds may know by experience that their last year's breeding grounds offer all these basic resources.

It has been said that for the many aspects on the migration of birds nobody surpassed Frederick before the times of Konrad Lorenz, one of the founders of ethology (Stresemann, 1951).

\section{EXPERIMENTALIST}

Frederick also experimented with his hawks and vultures (Egerton, 2003). He tested whether vultures find their food using their sense of smell or sense of eyesight. Frederick wrote: "A vulture is not attracted to his carrion food by a sense of smell, although some writers maintain that he is, but relies on his eyesight. We have ourselves 


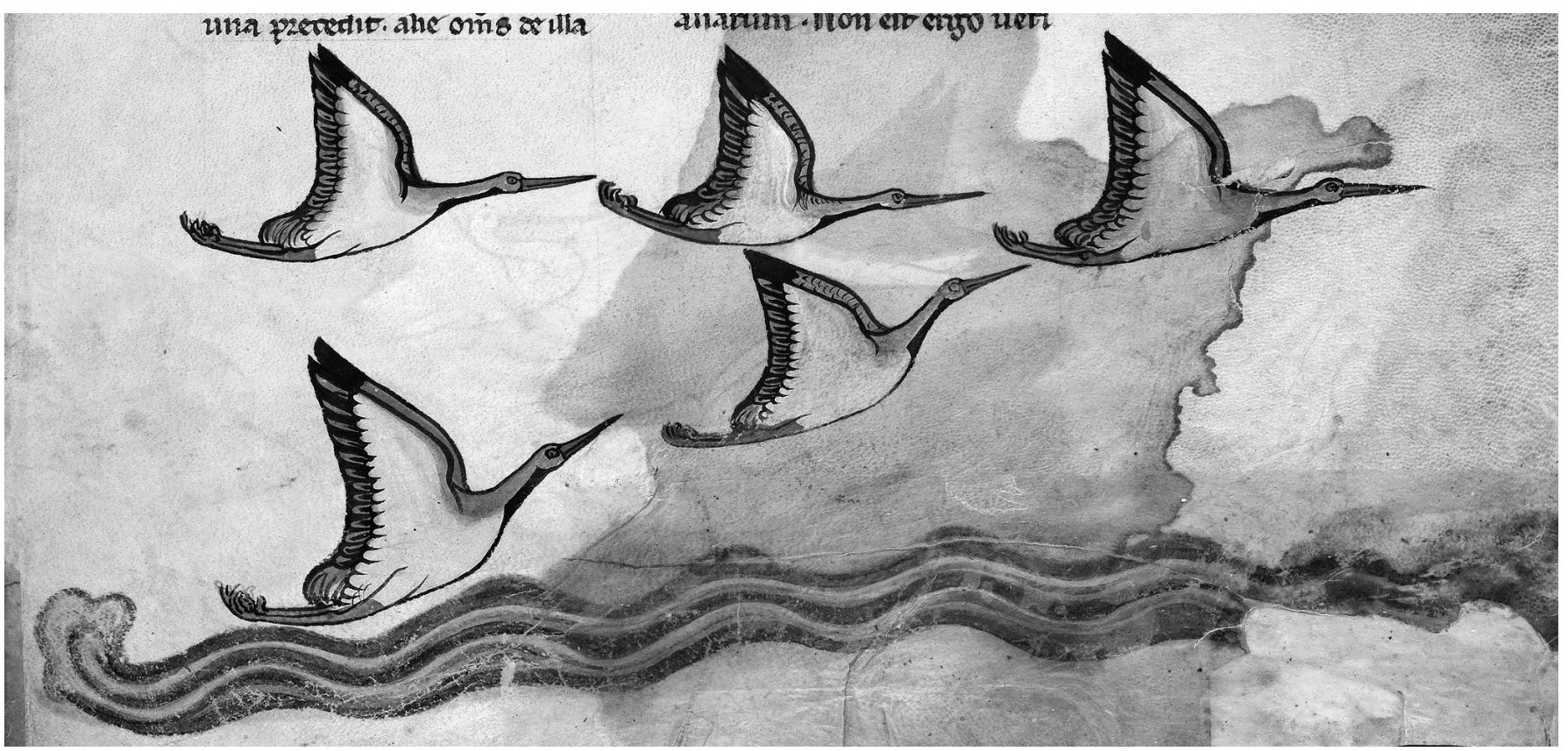

Fig. 5 - Frederick was a keen observer of migrating large birds, among them cranes. / Federico era un acuto osservatore dei grandi uccelli migratori, tra cui le gru. (C) Biblioteca Apostolica Vaticana, Pal.lat.1071: f.16r.

many times experimented and observed that an assemblage of seeled vultures ${ }^{4}$, whose noses were not stopped up, did not scent the meat cast before them. We have also made observation that vultures, even when hungry, will not catch live birds and refuse to seize chickens when thrown to them alive and before their eyes but which they eat after they have been killed" (Wood \& Fyfe, 1955: 22). (Fig. 6).

Frederick also experimented with the hunting behaviour of his trained hawks (Egerton, 2003: 41-43) ${ }^{5}$. He trained falcons to hunt cranes and herons, which they do not normally do because of the large size and defensive capacity of these species of prey. He achieved this with his trainers by training a pair of falcons to hunt together, along with their trainers.

Frederick's experiments were not limited to predation or predatory birds only. Frederick was very interested in cuckoos and their nesting behaviour. He was aware of the cuckoo's parasitic nesting habit but wanted to confirm it experimentally: "We have verified this fact from actual

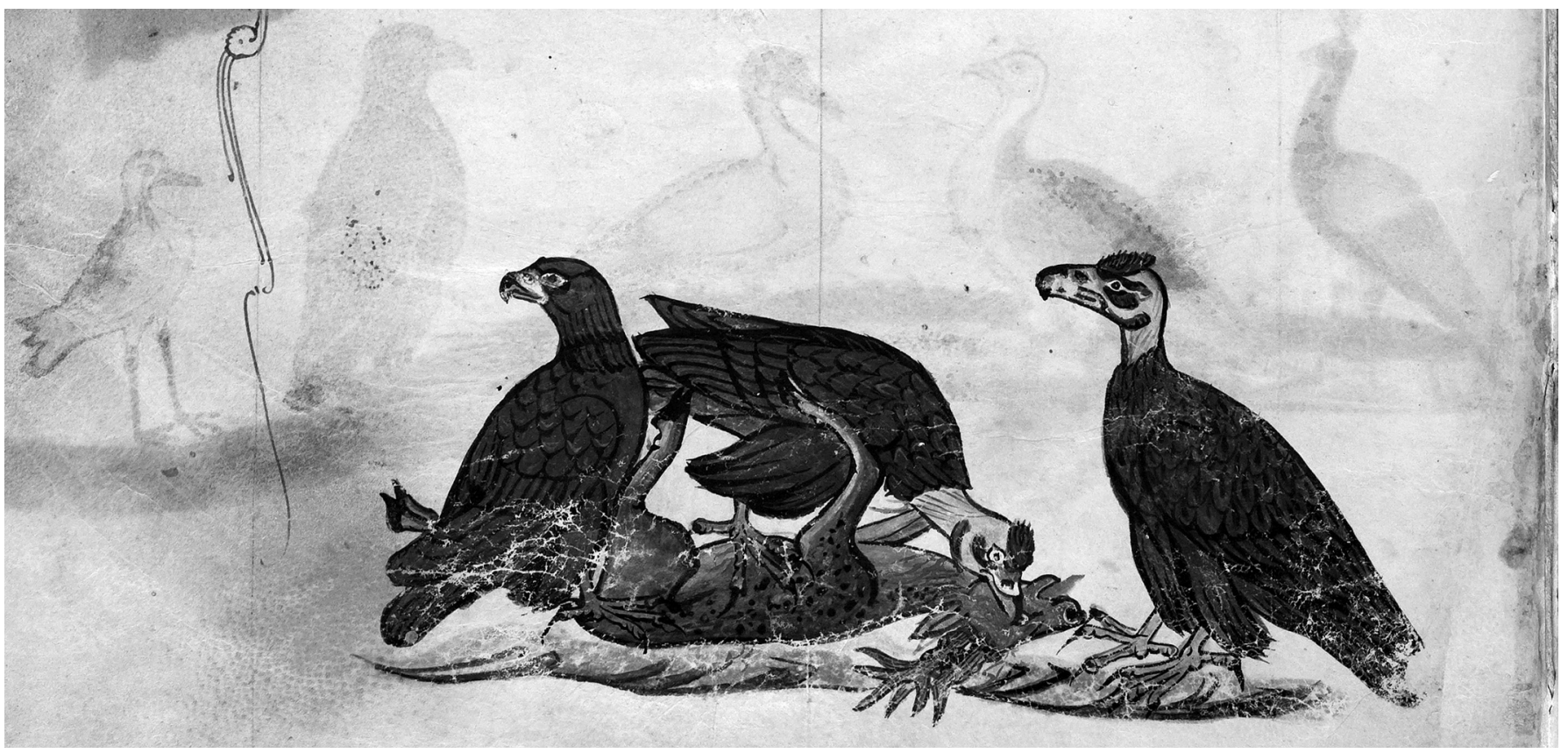

Fig 6 - Cinereous Vultures feeding on a carcass (center and right). Frederick conducted several experiments on the feeding behavior of vultures. / Avvoltoi monaci che si nutrono di una carcassa (al centro e a destra). Federico condusse diversi esperimenti sul comportamento alimentare degli avvoltoi. (C) Biblioteca Apostolica Vaticana, Pal.lat.1071: f.4v. 
experience". A strange-looking nestling "with immense mouth" was brought to Frederick and he was able to establish its identity by feeding it carefully "and, behold, on maturity we saw that it was a young cuckoo" (Wood \& Fyfe, 1955: 49-50). He was also aware that the ostrich does not incubate its own eggs. Instead, the extreme heat of the sun, "warming the sand in which eggs are deposited is sufficient to hatch them. A similar phenomenon is to be observed in Egypt, where eggs of the barnyard fowl are kept warm and the young hatched out independent of the mother bird. We ourselves saw this and we arranged to have it repeated in Apulia by experts whom we summoned from Egypt" (Wood \& Fyfe, 1955: 53). A summary of Frederick's theoretical and empirical innovations in biology is listed in Table 1.

\section{FREDERICK'S LEGACY}

According to Ernst Mayr, "Frederick's genuine understanding of the living animal, so obviously based on personal experience, loomed large above the level of contemporary natural-history writings" (Mayr, 1982: 93). In addition to his contributions to ornithology, Frederick promoted early European science by having some of Aristotle's writings translated from Greek into Latin and by being a patron of the medical school of Salerno, where human bodies were dissected for the first time in more than one thousand years (Mayr, 1982: 93). After Frederick's death, the dissection of human bodies was again prohibited and physicians were obliged to rely for their human anatomy and physiology on classical traditions (Wood \& Fyfe, 1955: xxxvii).

He was very critical towards traditional beliefs. Frederick was able to show the popular belief that the barnacle geese are born from dead trees to be erroneous (White, 1984). "It is said that in the far north old ships are to be found in whose rotting hulls a worm is born that develops into a barnacle goose. This goose hangs from the dead wood by its beak until it is old and strong enough to fly. We have made prolonged research into the origin and truth of this legend and even sent special envoys to the North with orders to bring back specimens of those mythical timbers for our inspection. When we examined them, we did observe shell-like formations clinging to the rotten wood, but these bore no evidence to any avian body. We therefore doubt the truth of this legend in the absence of corroborative evidence" (Wood \& Fyfe, 1955: 51-52). (Fig. 7).

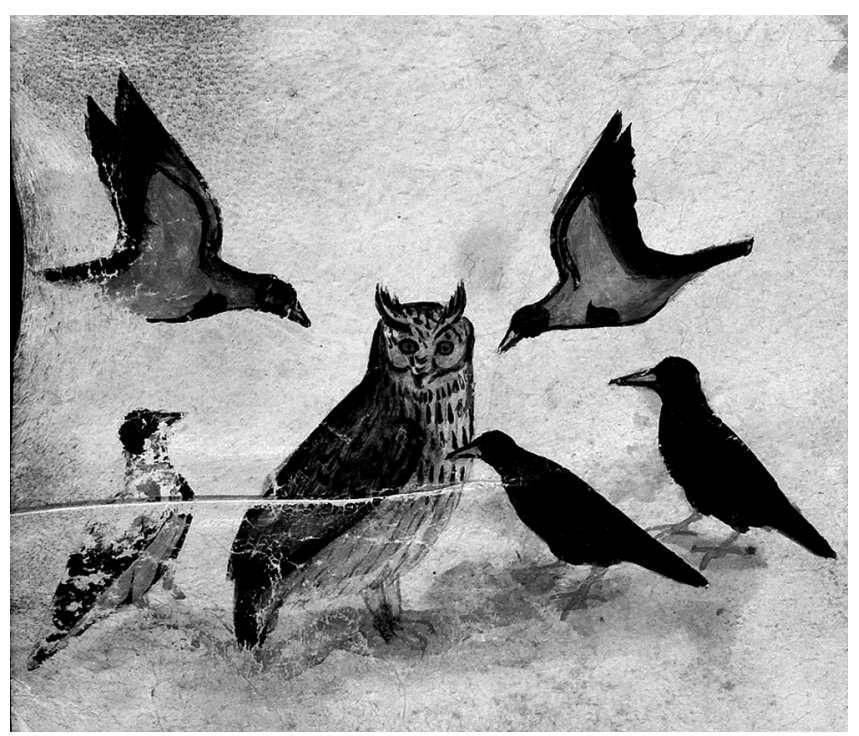

Fig 7 - Mobbing refers to cooperative antipredator behavior exhibited by many bird species. In this figure, Hooded and Carrion Crows harass an Eagle Owl, a typical predator of corvids. The famous ethologist Konrad Lorenz made this behavior familiar to his readers in King Solomon's Ring, first published in 1949. / Il mobbing si riferisce al comportamento cooperativo antipredatorio esibito da molte specie di uccelli. In questa figura, delle cornacchie grigie e delle cornacchie nere molestano un gufo reale, un tipico predatore di corvidi. Il famoso etologo Konrad Lorenz ha reso questo comportamento familiare ai suoi lettori ne L'anello di Re Salomone, pubblicato per la prima volta nel 1949. (C) Biblioteca Apostolica Vaticana, Pal.lat.1071: f.10v.

Tab.1 - Frederick's theoretical and empirical innovations in biology. / Le innovazioni teoriche ed empiriche di Federico in biologia.

\begin{tabular}{|l|l|}
\hline Aristotle's criticism & Disagreement with definitions and many natural history observations; ecological classification of birds. \\
\hline Biogeography & $\begin{array}{l}\text { Geographical variation in the morphology and behavior of birds (Bergmann's rule). Individuals in bird populations } \\
\text { tend to be of a larger size in cold than in warm areas. }\end{array}$ \\
\hline Predation & $\begin{array}{l}\text { Avoidance of predators may explain the birds' diurnal movements, flocking behavior, and sleeping on one foot (by } \\
\text { enhanced alertness). An individual bird encountering a predator is safer in a flock than being alone. }\end{array}$ \\
\hline Ecosystem trophic structure & Prey species are more abundant than their predators. \\
\hline Mate choice behaviour & $\begin{array}{l}\text { Bird voices have an important role in finding potential mates. Frederick, however, did not mention the importance of } \\
\text { any particular physical characteristics. }\end{array}$ \\
\hline Parent-offspring relations & $\begin{array}{l}\text { Offspring demand more attention and care from their parents than parents are motivated to provide. According to } \\
\text { modern behavioural ecology, this is based on the genetic selfishness of individuals. }\end{array}$ \\
\hline Kin selection & $\begin{array}{l}\text { Avoidance of competitive interactions among individuals of close kin. According to kin selection theory, individuals } \\
\text { should avoid competition with their close relatives because they carry copies of same genes. }\end{array}$ \\
\hline Seasonal migration & $\begin{array}{l}\text { Main causes are preference for mild temperature, food scarcity and avoidance of predation; timing of migration } \\
\text { depends on geographical location; differences between spring and autumn migration. }\end{array}$ \\
\hline Experiments & The role of different senses in finding prey in vultures, cooperative hunting in falcons, cuckoo nestling growth. \\
\hline
\end{tabular}


Frederick was also well aware of the role of the nutrition in the welfare of birds and he also gave interesting advice for modern gourmands. He observed that each bird species is specialized with regard to its own kind of food, and the digestive systems of different bird species are specialized to their own specific food. He continued: "From this diversity of food which various avian species are accustomed to eat, the diligent investigator may learn on what fare individual birds are best nourished and the best kind of food to give them. This role not only applies to rapacious birds kept by man but may well indicate what birds form the best nourishment for human beings themselves - which species are inferior as food, which are suitable, and which are unsuitable for man's consumption. It may be affirmed that, as human fare, those animals that eat both flesh and other food indifferently supply us with inferior meat and poor nourishment." (Wood \& Fyfe, 1955: 31).

He noted that birds that consume fish preferentially are the least desirable food sources for humans. On the contrary, birds that eat grain, grass and fruit furnish good meat and nourishment, while those that "live on grain alone make the ideal diet and provide by far the most tasty and most nourishing food" (Wood \& Fyfe, 1955: 31). So, obviously, partridge might be the most recommended food item to be found among birds.

Frederick's cultural achievements included the founding of the University of Naples in 1224 CE, the first university to be definitely established by a charter. In his cosmopolitan court, poetry and other branches of literature flourished with close commercial and cultural relations to the Muslim and Jewish worlds. Indeed, some scholars since Kantorowitz have even suggested that the real beginning of the Italian Renaissance should be sought in Frederick's court (Kantorowitz, 1933; Wood \& Fyfe, 1955: xxxvi-xxxvii). ${ }^{6}$

Due to his controversies with the Pope, Frederick died without absolution in $1250 \mathrm{CE}$. He was thus considered a heretic, and his writings were prohibited by the Church. This is probably why the De arte venandi cum avibus suffered a damnatio memoriae. In 1756, it was translated into German, but Frederick's impact on development of ornithology remained minimal until 1788, when his great work was rediscovered by J. G. Schneider, although a printed edition had already been published in 1596 in Augsburg, and L'Ornithologia by Ulisse Aldrovandi (1522-1605) had also utilized the work widely (Chansigaud, 2009: 15) ${ }^{7}$.

\section{Acknowledgements}

We are grateful to the Biblioteca Apostolica Vaticana and the Institutum Romanum Finlandiae in Rome for working facilities. We also thank the University of Turku Foundation for research room scholarship in the Granö Center, Tartu, Estonia.

\section{NOTES}

${ }^{1}$ The book by Wood \& Fyfe, 1955 includes a good English translation of the text; in our article, it has been compared with a newer Italian translation by Trombetti Budriesi, 2009.

${ }^{2}$ See also Yapp, 1983 and Kinzelbach: 2008a, 2008 b.
${ }^{3}$ See also Egerton, 2003: 2; Oggins, 2004: 3; Chansigaud, 2009: 21.

${ }^{4}$ Seeling refers to sewing the eyelids of the bird together.

${ }^{5}$ While it is true that Old World vultures mainly rely on their excellent eyesight to find carcasses, the situation is different for three species of New World vultures (cathartid vultures) that have an unusually well-developed sense of smell (Houston, 1994).

${ }^{6}$ For a different opinion, see Abulafia, 1988.

${ }^{7}$ For the fortunes of De arte venandi cum avibus see Trombetti Budriesi, 2009: 9, lxxii-lxxiii, lxxxv-lxxxviii.

\section{REFERENCES}

Abulafia D., 1988 - Frederick II: a medieval emperor. Allen Lane. London.

Chansigaud V., 2009 - History of Ornithology. New Holland Publishers. London.

Dementiev G. P., 1935 - Sur le prédécesseurs de Bergmann. Bulletin de la Société impériale des naturalistes de Moscou, Section biologique, 44: 338-340. (In Russian with French summary).

Egerton F. N., 2003 - A History of the Ecological Sciences, Part 8. Frederick II of Hohenstaufen: Amateur Avian Ecologist and Behaviorist. Bulletin of the Ecological Society of America, 84 (1): 40-44.

Houston D. C., 1994 - Family Cathartidae (New World Vultures). In: Handbook of the Birds of the World. Volume 2. New World Vultures to Guineafowl. del Hoyo J., Elliott A. \& Sargatal J. (eds.). Lynx Edicions, Barcelona: 24-41.

Kantorowitz E., 1933 - Frederick the second: 1194-1250. Constable, London.

Kinzelbach R. K., 2008a - Pre-Linnean pictures of the secretarybird, Sagittarius serpentaries (J. F. Müller, 1779). Archives of Natural History 35: 243-251.

Kinzelbach R. K., 2008b - Modi auium. Die Vogelarten im Falkenbuch des Kaisers Friedrich II. In: Von der Kunst mit Vögeln zu jagen. Das Falkenbuch Friedrichs II. Kulturgeschichte und Ornithologie. Begleitband zur Sonderausstellung Kaisers Friedrich II (11941250). Welt und Kultur des Mittelmeerraumes im Landesmuseum fur Natur und Mensch, Oldenburg. Fansa M. \& Ritzau C. (eds.). Philipp Von Zabern, Mainz am Rhein, Schriftenreihe des Landesmuseums für Natur und Mensch, Oldenburg, 56: 62-135.

Leroi A. M., 2014 - The Lagoon. How Aristotle invented science. Bloomsbury Publishing: 88-90.

Mayr E., 1982 - The Growth of Biological Thought. Diversity, Evolution, and Inheritance. The Belknap Press of Harvard University Press, Cambridge (MA).

Michod R. E., 1982 - The theory of kin selection. Annual Review of Ecology and Systematics, 13: 23-55.

Niemelä P., Salo J., Laaksonen H., 1991 - Frederick II of Hohenstaufen, Bergmann's rule and Aristotelian typology. Ornis Fennica, 68: 33-35.

Nordenskiöld E., 1928 - The History of Biology: A Survey. A. A. Knopf, New York.

Oggins R. S., 2004 - The Kings and Their Hawks. Falconry in medieval England. Yale University Press, New Haven \& London.

Stresemann E., 1951 - Die Entwicklung der Ornithologie von Aristoteles bis zur Gegenwart. F.W. Peters, Berlin.

Trivers R. L., 1974 - Parent-offspring conflict. American Zoologist, 14: 249-264.

Trombetti Budriesi A. L., 2009 - Federico II Svevia. De arte venandi cum avibus. L'arte di cacciare con gli uccelli. Edizione e traduzione italiana del ms. Lat. 717 della Biblioteca Universitaria di Bologna collazionato con il ms. Pal. Lat. 1071 della Biblioteca Apostolica Vaticana. Edizione Laterza, Roma-Bari.

White T. H., 1984 - The book of beasts: being a translation from a Latin bestiary of the twelfth century. Dover Publications, New York.

Willemsen C. A, 1980 - Das Falkenbuch Kaiser Friedrichs II. Die bibliophilen Taschenbücher, 152. Harenberg Kommunikation, Dortmund.

Wood C. A. \& Fyfe F. M., 1943 (1955 reprinted) - The art of Falconry: being the De arte venandi cum avibus of Frederick II of Hohenstaufen. Stanford University Press, Stanford, California. Reprinted Boston, Mass. and London.

Yapp W. B., 1983 - The illustrations of birds in the Vatican Manuscript of De arte venandi cum avibus of Frederick II. Annals of Science, 40 (6): 597-634. 